\title{
Financial Feasibility of Fig Cultivation (Ficus carica Linn.) in North-Eastern Karnataka, India
}

\author{
Lokappa $^{1}$, D.G. Satihal ${ }^{2}$, Suresh S. Patil ${ }^{3}$, G.M. Hiremath ${ }^{4}$ and Jaiprakash Narayan, R.P. ${ }^{5}$
}

${ }^{1}$ Department of Agricultural Economics, College of Agriculture, University of Agricultural Sciences (UAS), Raichur, India

${ }^{2}$ Senior Farm Superintendent, ARS, Bheemarayangudi, University of Agricultural Sciences (UAS), Raichur, India

${ }^{3}$ Dean (Agri), College of Agriculture, Bheemarayangudi, University of Agricultural Sciences (UAS), Raichur, India

${ }^{4}$ Asst Professor, College of Agriculture, University of Agricultural Sciences (UAS), Raichur, India

${ }^{5}$ Asst Professor, College of Agriculture, Bheemarayangudi, University of Agricultural Sciences (UAS), Raichur, India

*Corresponding author: dgsatihal@gmail.com

\begin{abstract}
The paper presents the costs and returns, economic and financial feasibility of fig cultivation in North Eastern region of Karnataka, India. Data collected from 60 fig cultivators by adopting multistage sampling design were analyzed using tabular analysis, economic and financial feasibility measures like Net Present Value (NPV), Internal Rate of Return (IRR), Benifit Cost (BC) ratio and Pay Back Period (PBP). The results revealed that, per acre total establishment cost was ₹ 1,23,626.73 of which, ₹ 55,607.30 (44.98\%) were variable cost and ₹ 68,019.40 (55.02\%) were fixed cost. Further, the analysis of investment in fig orchard suggests that, the investment made in fig cultivation in the study area was economically viable with BCR greater than unity (3.01), positive NPV (₹ 749986.40) and IIR higher than prevailing rate of interest $(12.00 \%)$. The payback period (3.44 years), was also desirable considering the total economic life of fig orchard. There is higher initial investment in fig orchards, therefore there is a need to provide financial assistance through enhanced scale of finance to the fig cultivators by institutional agencies to enhance the income of the farmers.
\end{abstract}

Keywords: Financial feasibility, NPV, BCR, PBP and Internal Rate of Return (IRR)

Fig (Ficus carica) is one of the ancient fruits known to mankind finds its mention in the Bible (30002000 BC) in the eastern Mediterranean region and is native of Southern Arabia. It is grown in all tropical and subtropical countries around the Mediterranean region, especially in Italy, Spain, Turkey, Greece, Portugal and Algeria. In India, its cultivation is mostly confined to western part of Maharashtra, Gujarat, Uttar Pradesh, Karnataka and Tamil Nadu (Anon., 2016). It is an important fruit and is consumed fresh or in processed form, the dried form being the most popular. It can also be canned or used for candy or jam making (Rajshree, 2007). There are various fig products commonly processed throughout the world, the dominant among these products are fig jam, fig pickle, dried figs, canned figs, fig preserve etc. In
India, fig cultivation is carried out in the area of 5600 hectares with the production of 13802 thousand tonnes and with the productivity of 12.32 tonnes per hectare (2014). In Karnataka its production is around 13099 Metric tonnes with an area of 1167 hectares with the productivity of 11.22 tonnes per hectare. In northeastern karnataka, as minor fruit crop is production is increasing significantly in the recent past because of its profitability. Literature review, however suggests the lack of scientific information about farm business data on its production cost, the accurate figures on its establishment cost, operating cost, and input requirement of fig orchard would be of great help to the fig cultivators, for making decision related to the enterprise. Hence the present paper examines the economics of fig production in the region. 


\section{Methodology}

The data were collected from 60 fig cultivators from two districts -Bellary and Kalburgi, adopting multistage random sampling design during the year 2016-17 using pretested specially designed schedule. The economic and financial feasibility measures viz., Costs and returns, Net Present Value (NPV), Benefit Cost Ratio (BCR), Pay Back Period (PBP) and Internal Rate of Return (IRR) were used.

Financial feasibility analysis: The financial feasibility of investment in fig orchard was carried out by developing year wise cash outflows and cash inflows for the fig orchard for the life period of 15 years. The financial feasibility of investment in fig orchard was judged with the help of following financial feasibility tests.

Net Present Value (NPV): It is nothing but present worth of the cash flow stream. The cash flow stream is weighted by the discount rate and then it becomes the discounted cash flows. The positive value of NPV is the criteria for selection of the project/ investment. NPV was estimated by using the formula:

Where, $\mathrm{B}_{\mathrm{t}}=$ benefit during $\mathrm{t}^{\text {th }}$ year

$$
\begin{aligned}
& C_{t}=\text { cost during } t^{\text {th }} \text { year } \\
& t=\text { time period } \\
& r=\text { discount rate at } 12 \text { per cent } \\
& \mathrm{n}=\text { fifteen years } \\
& I=\text { initial investment }
\end{aligned}
$$

Benefit- Cost ratio ( $B$ : $C$ ratio): It is the ratio of discounted benefits to the discounted costs. The projects having $B$ : $C$ ratio more than unity when discounted at the opportunity cost of capital is preferred.

Internal rate of return (IRR): It is the rate at which the present values (NPV) of the net cash flows are just equal to zero, i.e., $\mathrm{NPV}=0$. It was calculated by interpolation technique by using the formula:

$$
\begin{aligned}
& \text { Internal Lower Difference Present worth of the } \\
& \text { Rate of }=\text { discount }+ \text { between } \times \text { net benefits at the } \\
& \text { Return rate the two lower discount rate } \\
& \text { discount Absolute difference } \\
& \text { between the present } \\
& \text { worth of the net } \\
& \text { benefits at the two } \\
& \text { discount rates }
\end{aligned}
$$

Payback period (PBP): It is the length of time required to get back the investment on the project. In the present study, the payback period was calculated by successively deducting the initial investment from the net returns until the initial investment is fully recovered.

\section{RESULTS AND DISCUSSION}

An effort was made to estimate the cost and returns of fig orchard and to test the economic and financial feasibility of investment in fig orchards. The establishment cost per acre of fig orchard was estimated, considering the quantity of inputs, labour used, their respective market price and wages prevailed in the study area. The details of the findings on the establishment cost are presented in Table 1.

\section{Establishment cost of fig orchard}

Total establishment cost of fig orchard for two years was ₹ 123626 of which, variable cost accounted for 45 per cent (₹ 55607) and fixed cost was about 55 per cent of the total cost. The major items of expenditure in the total variable cost were: manure and manuring ₹ 10629 (8.19\%), fertilizer ₹ $8997.33(7.28 \%)$, inter cultivation ₹ $6610(5.34 \%)$ and digging and filling of pits ₹ $6350(5.14 \%)$. The other items of expenditure were planting material ₹ 6330 (5.12\%), fencing ₹ 4988 (4.03\%) and plant protection chemicals ₹ 2696 (2.18\%). Important items of the total fixed cost were irrigation charges ₹ $26023(21.05 \%)$, land rent ₹ $18333(14.83 \%)$ and depreciation ₹ 17557 (14.20\%). The interest on these fixed cost worked out to be ₹ 5616.28 (4.54\%).

It is observed that, the total cost in the first year was ₹ 72148.70, of which, ₹ 38139 was variable cost (52.86\%) and ₹ 34009 was fixed cost (47.14\%). Major expenditure among variable cost included was ₹ $6350(9.00 \%)$ accounted for digging and filling of pits followed by planting material ₹ 6330 $(8.77 \%)$, manure and manuring ₹ 5906 (8.19\%), fencing ₹ 4988 (6.91\%) and fertilizer ₹ 4327 (6.00\%). The expenditure on plant protection chemicals was ₹ $1417.83(1.96 \%)$ and staking ₹ $1120(1.55 \%)$. The interest charged on working capital at 7 per cent was ₹ 2495 (3.46\%). The major items among fixed cost included was irrigation charges ₹ 13011 (18.03) followed by land rent ₹ 9166.67 (12.71\%), depreciation ₹ 8778 (12.17\%) and land revenue 
₹ 2440 ( $0.34 \%)$. The interest charged on fixed capital at 12 per cent was ₹ 2808 (3.90\%).

Similarly, for the second year, total cost was ₹ 51477 of which, ₹ 17468 was variable cost $(33.93 \%)$ and ₹ 34009 was fixed cost $(66.07 \%)$. Important items of variable cost for the second year were manure and manuring ₹ 4723(9.18\%) followed by fertilizer ₹ 4670 (9.07\%), inter cultivation ₹ 3412 (6.63\%), plant protection chemicals ₹ $1278(2.48 \%)$ and training and pruning ₹ 2241 (4.35\%). Major components of the fixed cost were irrigation charges which constituted 25 per cent of the cost followed by land rent and depreciation accounted for about 17 per cent each. Interest on fixed capital was about 5 per cent of the total investment.

The costs of establishing fig orchard were higher (₹ 123626 per acre). It is mainly because of the higher cost of planting materials and intensive use of manure and fertilizer. The cost incurred on planting material ( $₹$ 6330) and digging \& filling of pits (₹ 6350) was the major component of the establishment cost. Because of higher profitability in fig crop many farmers shifted to fig cultivation. Hence, the availability of planting material was not sufficient to meet the demand of farmers. Therefore, fig seedlings were transported from distant places; because of this the cost of planting material was more.

Table 1: Establishment cost of fig orchard (₹/acre)

\begin{tabular}{ccccc}
\hline $\begin{array}{c}\text { S1. } \\
\text { No }\end{array}$ & Particulars & First year & $\begin{array}{c}\text { Second } \\
\text { year }\end{array}$ & Total \\
\hline A. & & \multicolumn{2}{c}{ Variable cost } \\
\hline 1 & Preparation & 2006.58 & - & 2006.58 \\
& of land & $(2.78)$ & & $(1.62)$ \\
2 & Planting & 6330.00 & - & 6330.00 \\
& material & $(8.77)$ & & $(5.12)$ \\
3 & Digging and & 6350.00 & - & 6350.00 \\
& filling pits & $(8.80)$ & & $(5.14)$ \\
4 & Manuring & 5906.16 & 4723.33 & 10629.49 \\
& & $(8.19)$ & $(9.18)$ & $(8.60)$ \\
5 & Fertilizer & 4327.33 & 4670.00 & 8997.33 \\
& & $(6.00)$ & $(9.07)$ & $(7.28)$ \\
6 & Inter & 3197.77 & 3412.30 & 6610.07 \\
7 & cultivation & $(4.43)$ & $(6.63)$ & $(5.34)$ \\
& Plant & 1417.83 & 1278.17 & 2696.00 \\
& protection & $(1.96)$ & $(2.48)$ & $(2.18)$ \\
& chemicals & & &
\end{tabular}

\begin{tabular}{|c|c|c|c|c|}
\hline 8 & $\begin{array}{c}\text { Cost of } \\
\text { supporting }\end{array}$ & $\begin{array}{c}1120.00 \\
(1.55)\end{array}$ & - & $\begin{array}{c}1120.00 \\
(0.90)\end{array}$ \\
\hline 9 & $\begin{array}{l}\text { Training and } \\
\text { pruning }\end{array}$ & $\begin{array}{c}00.00 \\
(0)\end{array}$ & $\begin{array}{c}2241.67 \\
(4.35)\end{array}$ & $\begin{array}{c}2241.67 \\
(1.81)\end{array}$ \\
\hline 10 & $\begin{array}{l}\text { Cost of } \\
\text { Fencing }\end{array}$ & $\begin{array}{c}4988.33 \\
(6.91)\end{array}$ & - & $\begin{array}{c}4988.33 \\
(4.03)\end{array}$ \\
\hline 11 & $\begin{array}{c}\text { Interest on } \\
\text { working } \\
\text { capital }\end{array}$ & $\begin{array}{c}2495.00 \\
(3.46)\end{array}$ & $\begin{array}{c}1142.78 \\
(2.22)\end{array}$ & $\begin{array}{c}3637.86 \\
(2.94)\end{array}$ \\
\hline I. & $\begin{array}{c}\text { Total } \\
\text { variable cost }\end{array}$ & $\begin{array}{c}38139.00 \\
(52.86)\end{array}$ & $\begin{array}{c}17468.25 \\
(33.93)\end{array}$ & $\begin{array}{c}55607.33 \\
(44.98)\end{array}$ \\
\hline B. & \multicolumn{4}{|c|}{ Fixed cost } \\
\hline 12 & $\begin{array}{l}\text { Land } \\
\text { revenue }\end{array}$ & $\begin{array}{c}244.50 \\
(0.34)\end{array}$ & $\begin{array}{l}244.50 \\
(0.47)\end{array}$ & $\begin{array}{l}489.00 \\
(0.40)\end{array}$ \\
\hline 13 & $\begin{array}{c}\text { Rental value } \\
\text { of land }\end{array}$ & $\begin{array}{c}9166.67 \\
(12.71)\end{array}$ & $\begin{array}{c}9166.67 \\
(17.8)\end{array}$ & $\begin{array}{c}18333.34 \\
(14.83)\end{array}$ \\
\hline 14 & Depreciation & $\begin{array}{c}8778.55 \\
(12.17)\end{array}$ & $\begin{array}{c}8778.55 \\
(17.05)\end{array}$ & $\begin{array}{c}17557.10 \\
(14.20)\end{array}$ \\
\hline 15 & Irrigation & $\begin{array}{c}13011.80 \\
(18.03)\end{array}$ & $\begin{array}{c}13011.80 \\
(25.28)\end{array}$ & $\begin{array}{c}26023.70 \\
(21.05)\end{array}$ \\
\hline 16 & $\begin{array}{l}\text { Interest on } \\
\text { fixed capital }\end{array}$ & $\begin{array}{c}2808.14 \\
(3.9) \\
\end{array}$ & $\begin{array}{c}2808.14 \\
(5.46) \\
\end{array}$ & $\begin{array}{c}5616.28 \\
(4.54) \\
\end{array}$ \\
\hline II. & $\begin{array}{c}\text { Total fixed } \\
\text { cost }\end{array}$ & $\begin{array}{c}34009.70 \\
(47.14)\end{array}$ & $\begin{array}{c}34009.70 \\
(66.07)\end{array}$ & $\begin{array}{c}68019.40 \\
(55.02)\end{array}$ \\
\hline & $\begin{array}{l}\text { Total cost } \\
\text { (I+II) }\end{array}$ & $\begin{array}{c}72148.70 \\
(100)\end{array}$ & $\begin{array}{c}51477.95 \\
(100)\end{array}$ & $\begin{array}{c}123626.73 \\
(100)\end{array}$ \\
\hline
\end{tabular}

Note: Interest on working capital was @ 7 per cent; Interest on Fixed capitalwas@9percent.

Cost of manure and fertilizer was around ₹ 10629 and ₹ 8997 respectively. Since nutrients are prone to heavy losses in soils, farmers in study area practiced application of high manures and fertilizer doses. Organic cultivation practices may be explored and farmers may be guided properly through extension network to reduce the cost of cultivation by proper management of fertilizer and manure application.

\section{Maintenance cost of fig orchard}

It is observed from the Table 2 that, the average per acre cost incurred by growers of fig for the maintenance of orchard during bearing period was $₹ 59682$ of which, about 28 per cent (₹ 16689) was on variable cost and as high as 72 per cent (₹ 42993) was fixed cost. Among variable cost, major components of the labour cost were weeding ₹ 1980 (3.32 \%) followed by harvesting ₹ 1834 (3.07\%) and application of plant protection chemicals ₹ 741 (1.24\%). Application of fertilizers (₹ 522), application 
of FYM (₹ 498) and miscellaneous charges accounted for less than 1 per cent of the total cost. The major items of material cost were cost of FYM (₹ 4934), cost of fertilizer ( $₹ 4653$ ) and cost of plant protection chemicals ( $₹ 1274$ ), together accounted 27.96 per cent of the total maintenance cost.

The fixed cost was accounted for 72 per cent of the total cost, of which major cost was on irrigation charges (₹ 13011) followed by rent paid to land ( $₹$ 9166), depreciation ( $₹ 8778$ ), amortized establishment cost (₹ 8241), interest on fixed capital (₹ 3549) and land revenue (₹ 244).

It is seen in the study area that farmers of fig did not use FYM as the availability of quality FYM was very less and the requirement of FYM for fig was also very huge. Hence, fig growers in this area resorted to use higher doses of fertilizers to supplement the nutrient requirements, which led to increased fertilizer cost. The measures suggested in establishment cost section may also be considered to reduce the cost of maintenance. Due to the use of large amount of plant protection chemicals (PPC) at flowering, fruit setting, fruit developing, cost of PPC was also high compared to other cost item.

Cost and returns of fig production

The cost and returns of fig production is depicted in the Table 3. It is observed that, the average fig yield recorded among the sample farmers was 40.70 quintal per acre. The total cost of cultivation was ₹ 59682, the cost of marketing was ₹ 10006.91 and total cost incurred was ₹ 69689.

Table 2: Maintenance cost of fig orchard (₹/acre)

\begin{tabular}{|c|c|c|c|c|c|}
\hline $\begin{array}{l}\text { Sl. } \\
\text { No. }\end{array}$ & Particulars & Unit & Quantity & Value & Per cent \\
\hline I. & \multicolumn{5}{|c|}{ Variable cost } \\
\hline A. & \multicolumn{5}{|c|}{ Labour cost } \\
\hline 1 & $\begin{array}{l}\text { Application } \\
\text { of FYM }\end{array}$ & Man days & 3.75 & 498.00 & 0.83 \\
\hline 2 & $\begin{array}{l}\text { Application } \\
\text { of Fertilizers }\end{array}$ & Man days & 3.60 & 522.50 & 0.87 \\
\hline 3 & $\begin{array}{l}\text { Application } \\
\text { of PPC }\end{array}$ & Man days & 2.70 & 741.00 & 1.24 \\
\hline 4 & Weeding & Man days & 14.00 & 1980.50 & 3.32 \\
\hline 5 & Harvesting & Man days & 13.63 & 1834.83 & 3.07 \\
\hline 6 & Miscellaneous & Man days & - & 250.30 & 0.42 \\
\hline & $\begin{array}{c}\text { Total labour } \\
\text { cost }\end{array}$ & $₹$ & - & 5827.13 & 9.76 \\
\hline
\end{tabular}

\begin{tabular}{|c|c|c|c|c|c|}
\hline B & \multicolumn{5}{|c|}{ Material cost } \\
\hline 1 & FYM & Tonnes & 2.00 & 4934.33 & 8.27 \\
\hline 2 & Fertilizers & Kgs & 199.00 & 4653.33 & 7.80 \\
\hline 3 & PPC & $\mathrm{Kgs}$ & 3.98 & 1274.66 & 7.79 \\
\hline & $\begin{array}{c}\text { Total } \\
\text { material cost }\end{array}$ & $₹$ & - & 10862.32 & 18.20 \\
\hline & $\begin{array}{c}\text { Subtotal } \\
(\mathrm{A}+\mathrm{B})\end{array}$ & ₹ & - & 16689.45 & 27.96 \\
\hline II & \multicolumn{5}{|c|}{ Fixed cost } \\
\hline 1 & $\begin{array}{c}\text { Rental Value } \\
\text { of land }\end{array}$ & $₹$ & - & 9166.67 & 15.36 \\
\hline 2 & Land revenue & $₹$ & - & 244.50 & 0.41 \\
\hline 3 & $\begin{array}{c}\text { Amortized } \\
\text { establishment } \\
\text { cost }\end{array}$ & $₹$ & - & 8241.78 & 13.81 \\
\hline 4 & Depreciation & $₹$ & - & 8778.55 & 14.71 \\
\hline 5 & Irrigation & $₹$ & - & 13011.80 & 21.80 \\
\hline 6 & $\begin{array}{l}\text { Interest on } \\
\text { fixed cost }\end{array}$ & $₹$ & - & 3549.89 & 5.95 \\
\hline & $\begin{array}{c}\text { Total fixed } \\
\text { cost }\end{array}$ & ₹ & - & 42993.19 & 72.04 \\
\hline & $\begin{array}{c}\text { Grand total } \\
(\mathrm{I}+\mathrm{II})\end{array}$ & ₹ & - & 59682.64 & 100.00 \\
\hline
\end{tabular}

Note: Interest on working capital was@ 7 per cent, Interest on fixed capital was@9 per cent

The average gross and net returns obtained among sample respondents was ₹ 139397 and ₹ 69707 per acre, respectively and per quintal cost of fig production was ₹ 1712 .

The average yield obtained per acre in case of fig was 40.70 quintals which was higher compared to other fruit crops growing in study area. This was mainly due to the improvement in technology, more use of fertilizers etc. However, it varies considerably from locality to locality depending upon the cultural practices adopted by the cultivators.

The average returns obtained from fig orchard was ₹ 69707.95 per acre. Due to fruits richness in vitamins and minerals, though the fig cultivation confined to a limited area, demand for this fruit spread throughout the country. This is also one of the main reasons for more demand for the fruit. The results are similar with (Thorat et al. 2012).

\section{Financial feasibility of fig orchard}

To evaluate the feasibility of investment in fig orchards, the financial feasibility measures such as Net Present Value/worth, Benefit-Cost Ratio, 
Payback period and Internal Rate of Return were estimated and the results are presented in Table 4.

Net Present worth (NPW) or NPV: Net present value of an investment is the difference between the present value of series of cash inflows (returns) and outflows (costs) over the economic life period of the fig orchards. Net Present Value for the orchard in the study area was more than zero ₹ 749986 per acre at 12 per cent discount rate, indicating that fig production is profitable venture in the study area.

Benefit Cost Ratio (BCR): The Benefit Cost Ratio indicates the rate of return per rupee invested in fig orchards. The benefit-cost ratio at 12 per cent discount rate was more than one (3.01) for the orchards suggesting a rupee investment in fig production generates ₹ 3 .

Table 3: Cost \& returns of fig production (Per acre)

\begin{tabular}{ccccc}
\hline $\begin{array}{c}\text { Sl. } \\
\text { No. }\end{array}$ & Particulars & Unit & Quantity & Value \\
\hline 1 & Yield & (qtl) & 40.70 & 139397.50 \\
2 & Total cost of cultivation & $₹$ & - & 59682.64 \\
3 & Marketing cost & $₹$ & - & 10006.91 \\
4 & Total cost & $₹$ & - & 69689.55 \\
5 & Gross returns & $₹$ & - & 139397.50 \\
6 & Net returns & $₹$ & - & 69707.95 \\
7 & Per quintal cost of & $₹$ & - & 1712.27 \\
\hline
\end{tabular}

Note: Average price received by the farmers was ₹ 3425 per quintal.

Pay Back Period (PBP): Pay Back Period is the period required to recover the initial investment incurred in establishing the orchard. In the present study the payback period was about 3.44 years for the orchards, it indicates that it would take 3.44 years to recover the entire investment.

Internal Rate of Return (IRR): The Internal Rate of Return criterion measures the rate of return that can be realized by investment of the returns in fig orchard. The IRR is an important basis of investment and better than other criteria of evaluation, which do not consider the reinvestment opportunities. The value of IRR generally depends on the magnitude of returns realized in each year over the economic life period and more particularly in the initial years of fig production. It could be noted here that, the IRR was found to be 48 per cent for the orchards, indicating that the investment in fig orchard is highly profitable, economically feasible and financially viable. Thus all the financial feasibility measures show favorable option for fig cultivation in the study area. Similar results were found by (Ravikumar et al. 2011).

Table 4: Financial feasibility of investment in fig orchard

\begin{tabular}{cccc}
\hline $\begin{array}{c}\text { Sl. } \\
\text { No. }\end{array}$ & Particulars & Units & value \\
\hline 1 & Net Present Value (NPV) @ 12\% & ₹ & 749986.40 \\
& discount rate & & \\
2 & Benefit Cost Ratio @ 12\% & & 3.01 \\
& discount rate & & \\
3 & Internal Rate of Return (IRR) & $\%$ & 48.00 \\
4 & Pay Back Period (PBP) & Yr. & 3.44 \\
\hline
\end{tabular}

\section{CONCLUSION}

The cost of establishment of fig orchards was around ₹ 123626 per acre. The NPV found to be positive (₹ 749986), the B: C ratio was greater than unity (3.01) and IRR 48.00 per cent which is higher than prevailing interest rate on borrowing and the payback period 3.44 years. The economic analysis of investment suggests that the investment made in fig orchard is economically and financially viable and found to be profitable venture in the region. Factual as well as anecdotal evidence suggest higher initial investment in fig orchards and need for financial assistance through enhanced scale of finance to the fig cultivators by institutional agencies.

\section{REFERENCES}

Anonymous., 2006. National Horticulture Mission Revised Action Plan for Karnataka. Report by Ministry of Agriculture, Government of India, 1-72.

Anonymous. 2012. Joint inspection team on its visit to Karnataka. Report of National Horticulture Mission, Ministry of Agriculture, Department of Agriculture and Cooperation. New Delhi. 1- 68.

Datarkar, S. B., Darekar, A. S., Dangore, U. T. and Parshuramkar, K.H. 2014. Economic of production and marketing of mango in Gadchiroli district of Maharashtra. Int. Res. J. Agric. Eco. E Stat., 5(2): 278-283.

Gupta, R.P., Bhonde, S.R., Gupta, P.K. and Sharma, H.P. 2012. Vision 2030. Report of National Horticulture Research and Development Foundation. 1-74.

Khuda, B., Ishtiaq, H. and Muhammad, S.A. 2006. Profitability and cost in growing mango orchards. J. Agri. Soc. Sci. 2(1): 46-50.

Rajshree, G.M. 2007. Economics of production and marketing of fig in Pune district. M. Sc (Agri.) Thesis, submitted to 
Mahatma Phule Krishi Vidyapeeth, Rahuri, Maharashtra (India).

Ravikumar, K.T., Hosamani, S.B., Mamle Desai, N.R., Suresh, D.E. and Ashalatha, K.V. 2011. Investment pattern and maintenance cost in pomegranate orchards: An economic analysis. Karnataka J. Agric. Sci., 24(2): 164-169.
Thorat, M.V. and Shelke, R.D. 2012. Economics of ber production in Beed district of Maharashtra. Int. J. Comm. $\mathcal{E}$ Bus. Mgt., 5(2): 207-209.

wWw.NABARD.org.in 